\title{
ANALISIS KUALITAS BUTIR SOAL FISIKA KELAS X SEKOLAH MENENGAH ATAS
}

\author{
Anita $^{1}$, Sulis Tyowati ${ }^{2}$, Zuldafrial ${ }^{3}$ \\ ${ }^{1,2}$ Program Studi Pendidikan Fisika IKIP PGRI Pontianak, Jalan Ampera Nomor 88 Pontianak \\ ${ }^{3}$ Program Studi Pendidikan Bahasa dan Sastra Indonesia IKIP PGRI Pontianak, Jalan Ampera \\ Nomor 88 Pontianak \\ 1e-mail: anitaummufaqih@gmail.com
}

\begin{abstract}
Abstrak
Penelitian bertujuan untuk mendeskripsikan kualitas butir soal pada bank soal Fisika secara kualitatif dan kuantitatif dan untuk mengetahui tingkat pemahaman siswa dalam menyelesaikan soal berdasarkan taksonomi Bloom pada mata pelajaran Fisika kelas X di SMA Negeri 2 Bunut Hulu Kabupaten Kapuas Hulu. Metode yang digunakan metode penelitian kombinasi, bentuk penelitian concurrent embedded strategy dan menggunakan rancangan penelitian kuadran IV. Hasil penelitian adalah: (1) Secara kualitatif berdasarkan konstruk, segi materi dan bahasa secara keseluruahn telah sesuai; dan (2) Secara kuantitatif berdasarkan proporsi tingkat kesukaran tidak seimbang. Daya pembeda 30\% kategori jelek, 37,5\% kategori cukup, 20\% kategori baik, 12,5\% sangat jelek. Efektivitas pengecoh $80 \%$ berfungsi, tingkat kevalidan sebesar $65 \%$, reliabilitas sebesar 0,65 dengan kategori sedang sehingga soal dapat dipercaya untuk mengevaluasi siswa, persentase jumlah kemampuan siswa yang mampu mengerjakan soal pada setiap aspek berdasarkan taksonomi Bloom C1 (pengetahuan) 70\%, C2 (pemahaman) 42,44\%, C3 (penerapan) 35,83\%, C4 (analisis) $18,33 \%$, dan tidak terdapat soal C5 dan C6.
\end{abstract}

Kata Kunci: kualitas, butir soal, analisis.

\begin{abstract}
This study aims to describe the analysis of the test questions quality on the items bank of physics subject qualitatively and quantitatively. This research also aims to know the percentage of students' understanding level in answering the test questions based on Bloom's taxonomy on the subject of physics grade X in SMA Negeri 2 Bunut Hulu Kapuas Hulu Regency. This study applies the mixed method research, through concurrent embedded strategy and quadrant IV research design. The results show in general: (1) The construction, the materials and the language of the test questions are appropriate qualitatively; and (2) the proportion of the difficulty level is unbalanced quantitatively. The categories of differentiating power are $12.5 \%$ very bad;30\% as bad; $37.5 \%$ as enough; $20 \%$ as good. The tricky questions are $80 \%$ effective; the validity rates are $65 \%$; the reliability is 0.65 as the moderate category so the question can be credible to evaluate the students; the percentages of students' capability on answering the questions in each aspect based on Bloom's taxonomy of C1 (knowledge) is70\%, C2 (understanding) is 42.44\%, C3 (application) is $35.83 \%$, C4 (analysis) is 18.33\%, C5 and C6 are not applicable.
\end{abstract}

Keywords: quality, test questions, analysis.

\section{PENDAHULUAN}

Soal tes (instrumen) merupakan salah satu alat yang dapat digunakan oleh guru untuk mengevaluasi seberapa besar penyerapan materi yang telah 
disampaikan dalam proses pembelajaran yang telah berlangsung. Soal yang baik adalah instrumen yang memenuhi syarat-syarat atau kaidah-kaidah tertentu, agar dapat memberikan data yang akurat sesuai dengan fungsinya (Arifin, 2010: 69). Liesfi (2016) menyatakan bahwa dalam proses evaluasi, tes yang baik adalah tes yang dapat menggambarkan keadaan siswa.

Langkah yang harus dilakukan untuk mengetahui tingkat kualitas suatu tes adalah dengan melakukan analisis kualitas tes. Analisis soal bertujuan untuk mengidentifikasi soal-soal yang baik, kurang baik dan soal yang tidak baik (Liesfi, 2016). Analisis soal harus memenuhi persyaratan yaitu, tingkat validitas, reliabilitas, objektivitas, praktikabilitas, dan ekonomis (Arikunto, 2005: 57). Daryanto (2007: 183) menyatakan bahwa analisis butir soal yang dikatakan baik apabila memiliki keterangan taraf kesukaran, daya pembeda, dan pola jawaban atau efektivitas pengecoh. Hal tersebut menunjukkan pentingnya dilakukan analisis butir soal baik dari segi tingkat kesukaran, daya pembeda, efektivitas pengecoh, validitas isi maupun konstruk serta reliabilitas soal.

Beberapa soal tes yang telah digunakan guru kemudian disimpan untuk dipergunakan kembali pada proses pembelajaran. Kumpulan dari soal-soal pada setiap tahun ajaran tersebut kemudian menjadi bank soal. SMA Negeri 2 Bunut Hulu memiliki bank soal diantaranya bank soal mata pelajaran Fisika. Bank soal digunakan untuk evaluasi pembelajaran pada akhir semester. Penyusunan bank soal dilakukan oleh guru Fisika di SMA Negeri 2 Bunut Hulu dengan sebagian soal diadopsi dari buku paket, lembar kerja siswa (LKS), dan beberapa soal dibuat sendiri oleh guru.

Hasil wawancara terhadap guru mata pelajaran Fisika di SMA Negeri 2 Bunut Hulu, diperoleh informasi bahwa guru belum melakukan analisis tes terhadap soal yang digunakan pada proses evaluasi. Dengan demikian belum diketahui kualitas alat evaluasi yang digunakan. Guru cenderung menggunakan soal-soal yang telah disusun dan diberikan pada siswa sebelumnya. Hal tersebut dikarenakan guru tidak memiliki waktu yang cukup untuk melakukan proses analisis tes yang digunakan. 
Berdasarkan pada permasalahan yang telah diuraikan dan untuk membantu guru dalam penelaahan soal yang akan diberikan agar soal yang digunakan dapat digolongan pada soal yang baik maka peneliti melakukan penelitian tentang analisis kualitas butir soal pada bank soal Fisika kelas X yang ada di SMA Negeri 2 Bunut Hulu Kabupaten Kapuas Hulu secara kualitatif dan kuantitatif. Melalui analisis kualitas butir soal, diharapkan memperoleh soal-soal bermutu yang dapat mengukur hasil pembelajaran dengan maksimal.

\section{METODE}

Metode penelitian menggunakan metode penelitian kombinasi (mixed methods research) yang menggabungkan atau menghubungkan metode penelitian kuantitatif dan kualitatif. Model kualitatif sebagai metode primer dan model kuantitatif sebagai model skunder. Rancangan penelitian menggunakan kuadran IV. Teknik pengumpulan data menggunakan teknik pengukuran dan studi dokumenter.

Teknik pengukuran dilakukan untuk memperoleh jawaban siswa dan studi dokumenter digunakan untuk memperoleh bank soal Fisika kelas X, kisi-kisi soal, kunci jawaban dan silabus. Alat pengumpulan data yaitu bank soal Fisika kelas $\mathrm{X}$ yang diperoleh dari SMA N 2 Bunut Hulu Kabupaten Kapuas Hulu. Soal berbentuk pilihan ganda berjumlah 40 soal dan lembar penelaah soal bentuk pilihan ganda.

Teknik analisis data dilakukan secara kualitatif dan kuantitatif. Analisis kualitatif dilihat dari segi materi, konstruksi, dan bahasa. Dianalisis menggunakan format penelaah soal bentuk pilihan ganda yang diadopsi dari Rahmadhani (2014) dan melibatkan 3 orang ahli yaitu 2 orang dosen Fisika IKIP PGRI Pontianak dan guru mata pelajaran Fisika. Analisis kuantitatif dilihat dari segi tingkat kesukaran, daya pembeda, efektivitas pengecoh, validitas, dan reliabilitas. Serta tingkat pemahaman siswa dalam menyelesaikan soal berdasarkan taksonomi Bloom yaitu pengetahuan, pemahaman, penerapan, analisis, sintesis, dan evaluasi. 


\section{HASIL DAN PEMBAHASAN}

\section{Analisis Kualitatif}

Terdapat soal yang tidak sesuai dengan indikator pencapaian yang direncanakan oleh guru dari segi materi. Soal yang ada juga tidak sesuai dengan keterpakaian dengan kehidupan sehari-hari (kontekstual), serta terdapat soal yang memiliki jawaban lebih dari satu jawaban sehingga soal yang ada harus direvisi kembali.

Soal yang mengacu pada ranah kognitif pada C1 sebanyak 2 soal, C2 sebanyak 2 soal, C3 sebanyak 28 soal, C4 sebanyak 8 soal, serta C5 dan C6 tidak terdapat pada soal. Jika dilihat dalam perbandingan yaitu 1:1:12:4. Hal tersebut tidak sesuai dengan prinsip kurva normal yang seharusnya $\mathrm{C} 1: \mathrm{C} 2: \mathrm{C} 3: \mathrm{C} 4$ memiliki perbandingan 1:2:2:1.

Soal nomor $3,9,13,15,18,20,32,33$, dan 35 tidak dirumuskan secara singkat, jelas, dan tegas dari segi konstruksi. Pernyataan yang dipaparkan seharusnya yang diperlukan saja. Soal nomor 6, 15, 18, 20, dan 35 memberikan petunjuk kunci jawaban. Soal nomor 6, 9, 10, 13, dan 15 gambar (grafik) yang disajikan tidak terlalu jelas. Hal tersebut dapat mempersulit siswa memahami soal. Soal nomor 18 dan 19 memiliki pernyataan yang negatif ganda. Seharusnya soal tidak boleh memiliki pernyataan yang negatif ganda karena akan mempersulit peserta tes dalam memahami maksud sari sebuah soal.

Soal nomor 13, 15, 16, 18, 20, 35, 38, dan 40 pilihan jawaban tidak homogen dan logis dilihat dari segi materi. Soal nomor 14, 15, 18, 24, 29, 30, dan 35 panjang pilihan jawaban relatif tidak sama. Soal nomor 18 dan 35 pilihan jawaban berbentuk angka dan tidak disusun berdasarkan besar kecilnya angka. Soal nomor 13 dan 16 pilihan jawaban mengulang kata/kelompok kata yang sama, sebaiknya pilihan jawaban tersebut direvisi sehingga pengecoh dapat bekerja secara efektif.

Soal nomor 13,14,15,18, dan 20 tidak sesuai dengan kaidah bahasa Indonesia dari segi bahasa dan budaya. Soal nomor 9, 13, 14,15, 18, dan 20 tidak menggunakan bahasa yang komunikatif. Sebaiknya tata bahasa pada soal tersebut direvisi kembali sehingga siswa lebih mudah memahami soal yang diberikan. 
Secara keseluruhan pada bank soal Fisika kelas X di SMA Negeri 2 Bunut Hulu Kabupaten Kapuas Hulu telah memenuhi aspek telaah. Namun ada beberapa soal yang belum memenuhi aspek tersebut. Oleh karenanya, soal tersebut sebaiknya direvisi kembali. Soal yang telah sesuai dapat dijadikan bank soal dan digunakan untuk mengevaluasi hasil belajar siswa.

\section{Analisis Secara Kuantitatif}

\section{Tingkat kesukaran}

Tingkat kesukaran merupakan pengukuran seberapa besar derajat kesukaran suatu soal sedangkan. Menurut Suprananto (2012: 175) tingkat kesukaran soal adalah peluang menjawab benar suatu soal pada tingkat kemampuan tertentu yang biasanya dinyatakan dalam bentuk indeks. Daryanto (2007: 180) menjelaskan besarnya indeks kesukaran antara 0,00 sampai dengan 1,0. Indeks kesukaran menunjukkan taraf kesukaran soal. Soal dengan indeks kesukaran 0,0 menunjukkan bahwa soal terlalu sukar, sebaliknya indeks 1,0 menunjukkan soalnya terlalu mudah.

Hasil perhitungan tingkat kesukaran pada 40 soal yang ada pada bank soal Fisika kelas X di SMA Negeri 2 Bunut Hulu Kabupaten Kapuas Hulu diperoleh kategori sukar sebanyak 26 soal, kategori sedang sebanyak 9 soal, dan kategori mudah sebanyak 5 soal dengan persentase $62,5 \%, 22,5 \%$, dan 12,5\%. Seperti yang ditunjukkan pada gambar berikut.

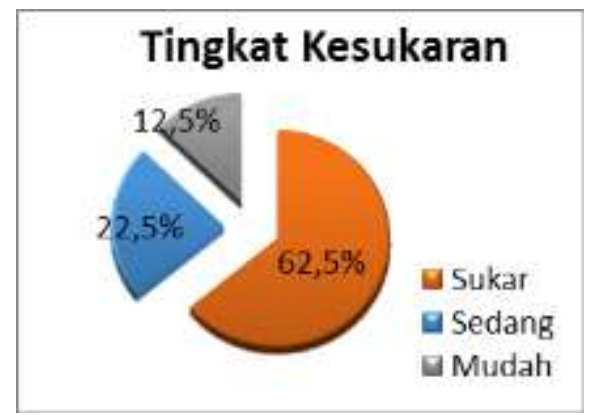

\section{Gambar 1 Diagram Tingkat Kesukaran Butir Soal}

Hasil perhitungan berdasarkan data yang terdapat pada Gambar 1 diperoleh perbandingan yaitu 25:9:5. Hasil perbandingan tersebut menunjukkan soal-soal pilihan ganda memiliki proporsi yang tidak seimbang. Soal yang terlalu mudah 
tidak membuat siswa mempertinggi usaha memecahkannya. Sebaliknya soal yang terlalu sukar akan menyebabkan siswa menjadi putus asa dan tidak mempunyai semangat untuk mencoba lagi karena diluar jangkauannya (Daryanto, 2007: 179).

Sebuah paket soal harus memiliki proporsi seimbang antara kategori sukar, sedang, dan mudah. Hal tersebut dijelaskan oleh Sudjana (2005: 136) sebaiknya sebuah paket soal yang diberikan kepada siswa memiliki keseimbangan tingkat kesukaran antara sukar:cukup:mudah dengan perbandingan 3:4:3 atau 2:5:3. Dengan demikian, dari 40 soal pada bank soal Fisika kelas X di SMA Negeri 2 Bunut Hulu tingkat kesukaran soal belum proposional. Sehingga perlu adanya pembagian yang proposional sesuai dengan tingkat kesukaran dalam sebuah paket soal yang diberikan kepada siswa.

\section{Daya pembeda}

Manurut Daryanto (2007: 183) daya pembeda soal adalah kemampuan sesuatu soal untuk membedakan antara siswa berkemampuan tinggi dengan siswa yang berkemampuan rendah, sehingga dapat memudahkan guru melakukan evaluasi pembelajaran.

Berdasarkan hasil perhitungan daya pembeda pada bank soal Fisika kelas X di SMA Negeri 2 Bunut Hulu Kabupaten Kapuas Hulu dari 40 soal diperoleh daya pembeda dengan kategori jelek berjumlah 12 soal, kategori cukup berjumlah 15 soal, kategori baik berjumlah 8 soal, kategori baik sekali berjumlah 0 soal, dan semuanya tidak baik berjumlah 5 soal dengan persentase jelek 30\%, cukup 37,5\%, baik $20 \%$ sangat baik $0 \%$, dan sangat jelek $12,5 \%$.

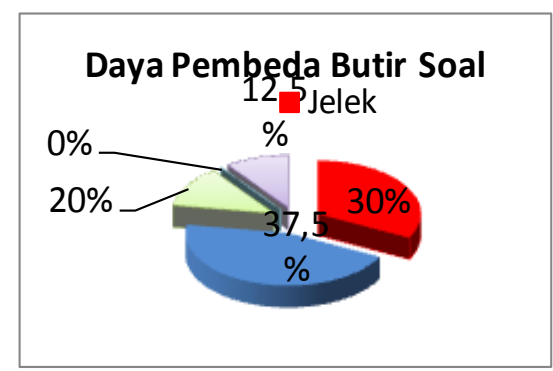

\section{Gambar 2 Persentase Daya Pembeda Butir Soal}

Soal yang berkategori cukup, baik, dan sangat baik dapat digunakan untuk mengevaluasi siswa, sedangkan kategori jelek dan sangat jelek tidak dapat 
digunakan. Soal dengan kategori jelek menunjukkan siswa berkemampuan tinggi dan siswa yang berkemapuan rendah dapat menjawab soal atau sebaliknya. Hal tersebut karena soal yang diberikan terlalu mudah sehingga semua siswa dapat menjawab soal dengan benar atau soal tersebut terlalu sukar sehingga siswa tidak dapat menjawab soal dengan benar.

Soal dengan kategori sangat jelek menunjukkan kualitas tes yang terbalik yaitu siswa yang berkemampuan tinggi tidak dapat menjawab soal sedangkan siswa yang bekemampuan rendah dapat menjawab soal. Ada kemungkinan pada saat mengisi soal siswa yang berkemampuan rendah menebak isian soal sehingga soal yang dijawab benar. Ada kemungkinan juga, siswa yang memiliki kemampuan rendah melakukan kecurangan dengan mencotek temannya yang berkemampuan tinggi.

Soal yang baik adalah soal yang lebih banyak bisa dijawab oleh siswa berkemampuan tinggi daripada siswa yang berkemapuan rendah, sehingga dapat membedakan antara keduanya. Hal tersebut dijelaskan oleh Sudaryono (2012: 179) yang menyatakan bahwa sebuah soal memiliki daya pembeda jika dapat dijawab dengan betul oleh kebanyakan siswa yang berkemampuan tinggi dan tidak dapat dijawab oleh kebanyakan siswa yang berkemampuan rendah.

Jumlah persentase soal yang dapat digunakan sebesar 57,5\% dan yang tidak dapat digunakan sebesar $42,5 \%$, maka dapat dikatakan dari 40 soal pada bank soal Fisika kelas X di SMA Negeri 2 Bunut Hulu Kabupaten Kapuas Hulu daya pembeda soal belum berfungsi dengan baik. Hal tersebut karena kedua persentase tersebut tidak jauh berbeda, oleh karenanya, soal yang memiliki daya pembeda yang tidak dapat digunakan sebaiknya dibuang saja.

\section{Efektivitas pengecoh}

Menurut Zuldafrial (2012: 114) analisis efektivitas pengecoh digunakan untuk menentukan apakah pengecoh sudah berfungi sebagai pengecoh dengan baik atau tidak. Menurut Daryanto (2007: 192) pengecoh dikatakan berfungsi dengan baik apabila pengecoh tersebut mempunyai daya tarik yang besar bagi peserta tes yang kurang memahami konsep atau menguasai bahan. 
Menurut Zuldafrial (2012: 114) pengecoh dapat dikatakan berfungsi dengan baik jika paling sedikit dipilih oleh $5 \%$ pengikut tes. Oleh karenanya, pengecoh dapat dikatakan berfungsi dengan baik jika memiliki daya tarik yang dapat mengalihkan pilihan jawaban siswa paling sedikit dipilih oleh 5\% dari jumlah siswa yang mengikuti tes. Pada penelitian diperoleh sebesar $2 \%$.

Berdasarkan hasil perhitungan efektivitas pengecoh pada bank soal Fisika kelas X di SMA Negeri 2 Bunut Hulu Kabupaten Kapuas Hulu diperoleh soal yang memiliki pengecoh berkategori berfungsi baik berjumlah 32 soal dengan persentase $80 \%$ dan yang tidak berfungsi berjumlah 8 soal dengan persentase $20 \%$. Hal tersebut dapat dilihat pada gambar berikut.

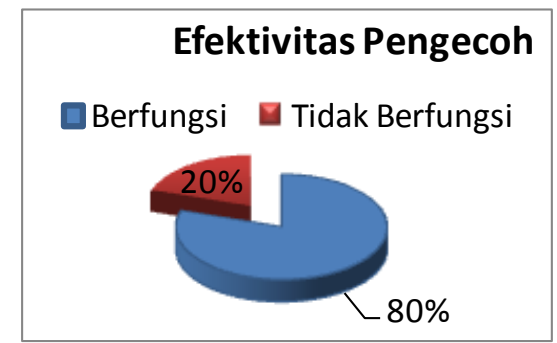

\section{Gambar 3 Persentase Efektivitas Pengecoh}

Adapun soal yang efektivitas pengecohnya tidak berfungsi yaitu pada soal nomor 1 pilihan jawaban A, D, dan E; soal nomor 2 pilihan jawaban A dan E; soal nomor 5 pilihan jawaban A dan E; soal nomor 9 dan 10 tidak memiliki kunci jawaban; soal nomor 15 pilihan jawaban E; soal nomor 16 pilihan jawaban A dan D; dan soal nomor 36 pilihan jawaban D.

Soal nomor 1, 2 dan 5 pengecoh soal tidak efektif. Siswa menjawab benar lebih banyak dari pada siswa yang menjawab salah. Hal tersebut dianggap siswa sudah menguasai materi dan pada tingkat kesukaran soal tersebut dikategorikan mudah. Pada soal nomor 9 dan 10 pengecoh tidak berfungsi. Jika dilihat dari kunci jawaban yang diberikan oleh sekolah terdapat pilihan jawaban yang benar. Namun, dilihat dari hasil perhitungan pada kisi-kisi soal tidak terdapat pada pilihan jawaban. Dengan kata lain, soal tidak memiliki kunci jawaban. Oleh karenanya, soal tersebut tidak dapat digunakan. Apabila soal tersebut ingin digunakan, maka pilihan jawaban harus direvisi terlebih dahulu. 
Soal 15, 16, dan 36 pengecoh tidak berfungsi. Jika dilihat dari hasil analisis secara kualitatif, soal nomor 15 pilihan jawaban tidak homogen dan logis serta panjang pilihan jawaban relatif tidak sama. Pada soal nomor 16, pilihan jawaban tidak homogen dan logis dilihat dari segi materi. Pada soal nomor 36, kunci jawaban hanya dipilih satu orang siswa saja dilihat dari tingkat kesukaran soal dikategorikan sukar.

Aprianto (Rahmani, 2014) menyatakan bahwa terdapat beberapa faktor yang mempengaruhi berfungsi atau tidaknya pengecoh yaitu soal terlalu mudah, pokok soal memberi petunjuk pada kunci jawaban dan siswa sudah menguasai materi. Tes pilihan ganda yang disusun tanpa memperhatikan homogenitas tidaknya pilihan jawaban akan berpeluang tidak berfungsi. Demikian juga jika pokok soal memberi petunjuk. Hal tersebut dikarenakan peserta tes akan dengan mudah menebak tanpa berpikir terlebih dahulu untuk memilih pilihan jawaban.

Daryanto (2007: 193) menyatakan bahwa efektivitas pengecoh yang baik dapat diterima sedangkan pengecoh yang tidak efektif dapat direvisi kembali. Sebagian besar efektivitas pengecoh pada bank soal Fisika di kelas X SMA Negeri 2 Bunut Hulu sudah berfungsi dengan baik dengan demikian efektivitas pengecoh dapat diterima dan digunakan. Sedangkan pengecoh yang belum berfungsi perlu diganti atau direvisi.

\section{Validitas}

Validitas adalah ketepatan suatu alat ukur dalam mengukur apa yang hendak diukur berdasarkan tujuan yang ingin dicapai. Berdasarkan hasil analisis validitas soal yang dikorelasi dengan skor total secara keseluruhan dari 40 soal diperoleh 25 soal atau 62,5 \% soal dikategorikan valid dan 15 soal atau 37,5\% soal diketegorikan tidak valid.

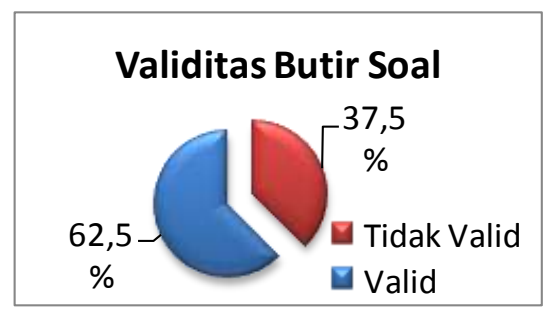

Gambar 4 Validitas Butir Soal 
Sudaryono (2012: 138) menyatakan bahwa suatu tes atau istrumen pengukuran dikatakan valid apabila alat tersebut menjalankan fungsi ukurnya atau memberikan hasil ukur yang sesuai dengan maksud dilakukannya pengukuran tersebut. Hal tersebut berarti hasil ukur dari pengukuran tersebut merupakan besaran yang mencerminkan secara tepat fakta atau keadaan sesungguhnya dari apa yang diukur.

Soal yang dikatakan valid yaitu soal yang mampu mengukur apa yang hendak diukur. Menurut Djaali (Sudaryono, 2012:138) suatu tes yang valid untuk tujuan tertentu, mungkin tidak valid untuk tujuan yang lain. Jadi validitas suatu tes harus selalu dikaitkan dengan tujuan. Dalam tes pencapaian hasil belajar, hasil tes diinterpretasikan sehingga dapat dievaluasi pencapaiannya berdasarkan tujuan yang telah direncanakan.

Sukardi (2010: 38) menyatakan bahwa ada beberapa faktor yang mempengaruhi validitas instrumen, diantaranya: faktor internal dari tes, faktor eksternal tes, dan faktor yang berasal dari siswa yang bersangkutan. Faktor internal tes seperti arahan tes yang disusun dengan makna tidak jelas sehingga dapat mengurangi validitas tes, tingkat kesulitan item tes tidak tepat dengan materi pembelajaran yang diterima siswa. Faktor eksternal tes seperti waktu pengerjaan tidak cukup sehingga siswa dalam memberikan jawaban dalam situasi tergesagesa, dan adanya kecurangan dalam tes sehingga tidak bisa membedakan antara siswa yang belajar dengan yang melakukan kecurangan. Fakor-faktor yang berasal dari siswa seperti sebelum tes siswa menjadi tegang karena situasi tes. Soal yang dinyatakan valid dapat dijadikan bank soal dan digunakan pada evaluasi selanjutnya. Sedangkan soal yang dinyatakan tidak valid soal tersebut dapat dibuang atau direvisi kembali.

\section{Reliabilitas}

Reliabilitas merupakan ketetapan atau keajegan alat ukur dalam menilai apa yang dinilai. Artinya, kapanpun alat penilaian tersebut digunakan akan memberikan hasil yang relatif sama. Hal tersebut juga dijelaskan Suprananto (2012: 82) reliabilitas merujuk pada konsistensi dari suatu pengukuran yaitu bagaimana skor tes konsisten dari pengukuran yang satu ke pengukuran lainnya. 
Menghitung reliabilitas bertujuan untuk mengetahui tingkat ketepatan dan keajekan skor tes. Indeks reliabilitas berkisaran antar 0 sampai dengan 1. Semakin tinggi koefisien reliabilitas suatu tes (mendekati 1), semakin tinggi pula keajekan atau ketepatannya (Suprananto, 2012: 177).

Berdasarkan hasil perhitungan reliabilitas pada bank soal Fisika kelas X di SMA Negeri 2 Bunut Hulu Kabupaten Kapuas Hulu diperoleh reliabilitas sebesar 0,65 dikategorikan reliabilitas sedang. Menurut Sukardi (2010: 51) salah satu yang mempengaruhi skor reliabilitas yaitu tingkat kesukaran. Soal yang terlalu mudah atau terlalu sulit untuk siswa cenderung mengahasilkan skor reliabilitas rendah. Hasil perhitungan terhadap tingkat kesukaran diperoleh tingkat kesukaran tidak proporsional sehingga mempengaruhi skor reliabilitas. Ada beberapa faktor yang dapat mempengaruhi reliabilitas, yaitu panjang tes, penyebaran skor, dan objektivitas.

Salah satu syarat agar hasil ukur suatu tes dapat dipercaya ialah tes tersebut harus mempunyai reliabilitas yang memadai (Sudaryono, 2012: 155). Oleh karenanya, bank soal Fisika kelas X di SMA Negeri 2 Bunut Hulu dapat dipercaya dan digunakan.

\section{Tingkat Pemahaman Siswa}

Tingkat pemahaman siswa merupakan salah satu patokan kompetensi yang dicapai setelah siswa melakukan kegiatan belajar. Pada aspek kognitif berdasarkan Taksonomi Bloom dibedakan atas enam ranah yaitu $\mathrm{C} 1$ (pengetahuan), C2 (pemahaman), C3 (penerapan), C4 (analisis), C5 (sintesis), dan C6 (evaluasi). Pengambilan keputusan ranah kognitif pada soal diambil dari salah satu atau semua ahli yang menganalisis. Soal yang digunakan pada pengukuran tingkat pemahaman menggunakan soal yang telah dinyatakan valid.

Hhasil analisis diperoleh soal yang valid yaitu C1 (pengetahuan) sebanyak 1 soal, C2 (pemahaman) sebanyak 3 soal, C3 (penerapan) sebanyak 16 soal, C4 (analisis) sebanyak 6 soal, serta tidak terdapat soal C5 (sintesis) dan C6 (evaluasi). Persentase jumlah kemampuan siswa yang mampu mengerjakan soal tersebut pada aspek C1 (pengetahuan) yaitu 21 orang atau 70\%. Pada aspek C2 (pemahaman) 
yaitu 38 orang atau 42,22\%. Pada aspek C3 (penerapan) yaitu 172 orang atau 35,83\%. Pada aspek C4 (analisis) yaitu 33 orang atau 18,33\%. Sehingga dapat dikatakan bahwa siswa lebih banyak bisa mengerjakan soal dengan tingkat pemahaman $\mathrm{C} 1$, kemudian $\mathrm{C} 2, \mathrm{C} 3$, dan $\mathrm{C} 4$.

Soal berbentuk pilihan ganda tidak terdapat jenjang C5 dan C6 hal ini karena jenjang C5 dan C6 tidak cocok untuk soal berbentuk pilihan ganda karena lebih sesuai dengan soal yang berbentuk essai (Rahmadhani, dkk., 2014: 435). Ranah kognitif C1, C2, dan C3 merupakan lower order thinking skills sedangkan pada C4, C5 dan C6 merupakan higher order thinking skill. Pada jenjang SMA siswa sudah mulai berpikir ke arah higher order thinking skill sehingga siswa sudah pada tahap C4. Sedangkan pada ranah kognitif C5 dan C6 tidak semua siswa pada jenjang SMA mampu untuk mencapai aspek tersebut.

\section{SIMPULAN}

Berdasarkan hasil pembahasan analisis soal pada bank soal Fisika kelas X di SMA Negeri 2 Bunut Hulu Kabupaten Kapuas Hulu, maka dapat disimpulkan: (1) Analisis secara kualitatif berdasarkan konstruk, materi, dan bahasa secara keseluruhan telah sesuai, namun ada beberapa soal yang perlu diperbaiki pada aspek konstruk, materi dan bahasa; (2) Analisis secara kuantitatif berdasarkan tingkat kesukaran, proporsi tingkat kesukaran tidak seimbang. Daya pembeda soal belum berfungsi dengan baik. Sebagian besar efektivitas pengecoh pada bank soal Fisika di kelas X SMA Negeri 2 Bunut Hulu sudah berfungsi dengan baik dengan demikian efektivitas pengecoh dapat diterima dan digunakan. Sebanyak $65 \%$ soal bernilai Valid. Reliabilitas 0,65 dengan kategori sedang sehingga soal dapat dipercaya untuk mengevaluasi siswa; dan (3) Kemampuan siswa dalam mengerjakan soal masih berada pada tingkat pengetahuan dan pemahaman.

\section{DAFTAR PUSTAKA}

Arifin, Z. 2009. Evaluasi Pembelajaran. Bandung: PT Remaja Rosdakarya. Arikunto, S. 2010. Dasar-Dasar Penelitian. Jakarta: PT Bina Aksara. 
Daryanto. 2007. Evaluasi Pendidikan. Jakarta: Rineka Cifta.

Liesfi, N. F. R. 2016. Analisis Butir Soal Ulangan Akhir Semester Ganjil Mata Pelajaran Teori Kejuruan Akuntansi. Jurnal Kajian Pendidikan Akutansi Indonesia. Hal: 1-11.

Subana \& Sudrajat. 2001. Statistik Pendidikan. Bandung: CV Pustaka Jaya.

Sudjana, N. 2005. Penelitian Hasil Proses Belajar Mengajar. Bandung: Remaja Rosdakarya.

Sudaryono. 2012. Dasar-Dasar Evaluasi Pembelajaran. Yogyakarta: Graha Ilmu.

Suprananto. 2012. Pengukuran dan Penilaian Pendidikan.Yogyakarta: Graha Ilmu.

Sukardi. 2010. Evaluasi Pendidikan: Prinsip \& Operasionalnya. Jakarta: Bumi Aksara.

Rahmadhani, E. K. 2014. Analisis Kualitas Butir Soal pada Bank Soal Biologi Kelas X SMA. Jurnal Bioedu, 3(1): 422-438.

Rahmani, M. 2014. Analisis Kualitas Butir Soal Ulangan Harian Buatan Guru Mata Pelajaran Biologi Kelas X SMA Negeri 1 Tanah Pinoh Tahun Pelajaran 2012/2013. Skripsi pada Fakultas FKIP, Universitas Tanjungpura Pontianak: diterbitkan.

Zuldafrial. 2012. Evaluasi Pendidikan \& Penelitian Tindakan Kelas. Pontianak: STAIN Pontianak Press. 